\title{
The use of glycerine as motor fuel
}

Glycerine as waste from production accounts for about 10\% of the obtained amount of biodiesel. It is a very attractive substance for the industry, however, currently the industry is not able to absorb such a large amount of glycerine produced during the production of fuel. Therefore, one should look for other ways of disposing of glycerol with simultaneous benefit in the form of energy yield or useful products / semi-finished products. The development of glycerine is necessary due to the continuous development of the biofuel market. In the near future, surplus glycerine may pose serious problems in the growth of biodiesel production. The publication presents the results of scientific research on the use of liquid technical glycerine and its processing products in the gasification process, as engine fuel.

Key words: internal combustion engines, glycerol, reforming processes, syngas, waste energy.

\section{Glycerine as an environmental problem}

Glycerine (glycerol) is one of the simplest trihydric alcohols. In pure form, it appears as a colorless, odorless, dense, hygroscopic liquid with a boiling point of $290^{\circ} \mathrm{C}$. It is well soluble in water and alcohols.

Glycerine is used in the pharmaceutical, cosmetics, food and chemical industries as a raw material for the production of plastics, cooling liquids and explosives.

In the modern world of motoring, where an ever stronger emphasis is placed on ecology, the share of fuels from renewable sources increases in place of existing fossil fuels. During the production of methyl or ethyl esters of fatty acids, constituting $3-20 \%$ of the biofuel additive, per ton of product is 90 to $110 \mathrm{~kg}$ of waste glycerine. Production of glycerine in 2005 reached 3.18 million tons. By 2020, biofuels are to constitute $20 \%$ of EU fuel fuels. In the US, diesel oil consumption is about 61 billion gallons annually, which assuming a $3 \%$ addition of biocomponents to biodiesel results in production of 810 thousand. $t$ glycerol annually [5]. With the economy's demand for glycerine of approx. 224,000 tons per year means a 4-fold surplus of production.

The crude glycerol obtained in the production of biodiesel, before the traditional process of utilization in a sewage treatment plant, must be subjected to purification, which results in additional costs included in the price of fuel production. In addition, the glycerine must be diluted so that it does not poison the biological deposit in the sewage treatment plant by increasing its volume.

If it is intended for the food or pharmaceutical industry, it must be subjected to additional purification processes consisting in the removal of acrolein-insoluble impurities and dehydration in order to meet the relevant standards. Cleansing glycerol from acrolein is not a problem, because it has high volatility.

Acrylic acid is already produced from acrolein. Acrylic acid is used for the production of polymers. A significant part is used for the production of absorbents for diapers and sanitary napkins. Ethylene glycol is used in fluids as a nonfreezing factor in engine cooling systems as well as cooling and heating systems. It is also used for the production of polyester resins, synthetic fibers, solvents, plasticizers and explosives. Nevertheless, this relationship is toxic and dangerous to life. It is withdrawn and replaced by propylene glycol, which is not toxic. At present, the methods for producing propylene glycol are based on the production of propylene oxide. In the years 2003-2006, a team of scientists from the USA improved the method of producing propylene glycol from glycerine making it much cheaper and safer.

The process of purification of glycerine obtained as waste from the production of biodiesel is highly energyconsuming, increasing the cost of its production. Table 1 illustrates the use of glycerine in the purified state.

Table 1. Share of glycerine applications in the market [5]

\begin{tabular}{|l|c|}
\hline Application & $\begin{array}{c}\text { Percentage on the } \\
\text { market }\end{array}$ \\
\hline pharmaceutical and cosmetics & 26 \\
\hline esters & 17 \\
\hline resins & 12 \\
\hline polymerisation component & 12 \\
\hline food & 10 \\
\hline chemistry & 10 \\
\hline cellulose processing & 5 \\
\hline nitroglycerine & 4 \\
\hline other & 4 \\
\hline
\end{tabular}

All these elements intensify the research on the development of glycerol.

The need arose for the new use of glycerol, especially in the unhydrated, raw state, which will reduce the costs of biodiesel production.

One of the ways of utilization can be to use it as a motor fuel or as an ingredient added to the fuel.

\section{Methods of using glycerine for energy purposes}

\subsection{Motor power supply with glycerine}

Glycerine is not a good motor fuel because of its parameters:

- calorific value of $1662 \mathrm{~kJ} / \mathrm{mol}, 18047 \mathrm{~kJ} / \mathrm{kg}$

- dynamic viscosity at $20^{\circ} \mathrm{C}$ is $1.5 \mathrm{~Pa} \cdot \mathrm{s}$

- kinematic viscosity at $25^{\circ} \mathrm{C}, 450-750 \mathrm{cSt}$

- heating value LHV $16 \mathrm{MJ} / \mathrm{kg}$

- density $1.260-11.261 \mathrm{~kg} / \mathrm{dm}^{3}$

- cetane number CN 0-10

The low calorific value, and in addition a high water content causes a reduction in the combustion temperature through the evaporation process. During this process, very 
toxic acrolein is formed. These features affect the big difficulties in using it as an independent motor fuel. Despite these unfavorable properties, attempts are made at various research centers to use it as an independent motor fuel to power internal combustion engines.

Initial research on the compression ignition engine power supply was carried out at the Czestochowa University of Technology [39] using the CRU chamber. It is a fixed combustion chamber with adjustable pressure and temperature parameters. Fuel was delivered to the combustion chamber using an electromagnetic injector. In the first tests glycerol was injected into the chamber without a pilot dose at various parameters of pressure and temperature prevailing inside the chamber. In the next stage, the process of burning glycerol with the pilot dose of diesel oil was observed.

The conclusions of these studies were:

- no possibility of burning pure glycerol in the CRU chamber due to its low cetane number,

- much slower course of glycerol combustion, especially in the final phase in relation to light diesel oil

- it is possible to burn glycerol with a pilot dose of diesel, but in this configuration its stability is very low

- the increase in glycerol injection time does not significantly affect the end of the combustion process and shows no correlation with the increase of injection pressure.

At the University of Warmia and Mazury in Olsztyn PhD Arkadiusz Rychlik and MSc Łukasz Kibalczyc [6] carried out research involving the feeding of a highpowered diesel engine with technical glycerine. The tests were carried out on the engine of the MTU V652 generator set.

To obtain favorable conditions for the combustion of glycerine in a compression-ignition engine, the following conditions should be adapted individually or possibly in combination:

- increasing the compression ratio

- increasing the cylinder fill ratio

- increasing the supply air temperature

The supply air was redirected through the heat exchanger, which increased the air temperature to $190-200^{\circ} \mathrm{C}$ from the initial $140^{\circ} \mathrm{C}$. The effect was to reduce the recharge pressure from 1.5 bar to 1.3 bar. Table 2 presents a part of the measurement results for powering the engine with diesel oil and glycerine. The engine was started and stopped using diesel. While working on glycerine, when the engine was thermally stabilized, an attempt was made to shut down and restart the engine. We managed to stop and restart the engine without any irregularities.

Table 2. Selected results of the glycerine burning tests in the ZS engine [6]

\begin{tabular}{|c|c|c|c|c|c|c|c|c|c|}
\hline Measurement & $\begin{array}{c}\text { Fuel } \\
\text { temp } \\
{\left[{ }^{\circ} \mathrm{C}\right]}\end{array}$ & $\begin{array}{c}\text { Power } \\
{[\mathrm{kW}]}\end{array}$ & $\begin{array}{c}\mathrm{CO} \\
{[\%]}\end{array}$ & $\begin{array}{c}\mathrm{CO}_{2} \\
{[\%]}\end{array}$ & $\begin{array}{c}\mathrm{HC} \\
{[\mathrm{ppm}]}\end{array}$ & $\begin{array}{c}\mathrm{O}_{2} \\
{[\%]}\end{array}$ & $\begin{array}{c}\mathrm{NOx} \\
{[\mathrm{ppm}]}\end{array}$ & $\begin{array}{c}\text { Exhaust } \\
\text { temp. } \\
{\left[{ }^{\circ} \mathrm{C}\right]}\end{array}$ & $\begin{array}{c}\text { Fuel } \\
\text { type }\end{array}$ \\
\hline 1 & 70 & 470 & 0.06 & 1.7 & 16 & 18.1 & 180 & 420 & $\mathrm{ON}$ \\
\hline 2 & 70 & 960 & 0.00 & 5.8 & 2 & 12.07 & 528 & 480 & $\mathrm{ON}$ \\
\hline 3 & 70 & 1200 & 0.00 & 4.4 & 5 & 14.2 & 528 & 525 & ON \\
\hline 4 & 100 & 1200 & 0.00 & 5.1 & 8 & 14.5 & 100 & 485 & Glic. \\
\hline 5 & 100 & 1200 & 0.01 & 5.2 & 10 & 15 & 120 & 480 & Glic. \\
\hline 6 & 100 & 1200 & 0.01 & 4.9 & 12 & 16 & 95 & 485 & Glic. \\
\hline
\end{tabular}

The conclusions and observations from the conducted tests are as follows:

- The use of technical glycerine as a fuel for the ZS engine enabled the proper functioning of the engine without disturbance for the duration of the tests.

- The combustion of technical glycerine in the ZS engine reduces $\mathrm{NO}_{\mathrm{x}}$ emissions. Studies have shown more than five times less emissions for diesel. The $\mathrm{CO}$ emission is lower when feeding with technical glycerine.

- The authors of the research indicate the guilt of operating the engine as the reason for the increased amount of HC emissions. During the tests, the permissible engine temperature was exceeded, which caused the lubricating oil to enter the combustion chamber.

- The consumption of technical glycerine as a fuel with $1200 \mathrm{~kW}$ load was about $14.25 \mathrm{dm}^{3} / \mathrm{min}$.

Taking into account the catalog diesel consumption, for this engine and the consumption of measured glycerine, the ratio of glycerine to diesel consumption is approximately 2.2: 1 .

\subsection{Supplying the SI engine with liquid fuel with the addition of glycerine}

The use of glycerol as an additive to conventional liquid fuels due to its hydrophilicity causes difficulty in creating a homogeneous mixture, and hygroscopicity, that there is a need to add a solvent compatible with the base fuels.

Professor Stelmasiak and dr Pietras from the University of Technology and Humanities in Bielsko-Biała conducted research [7] on the combustion of methanol mixtures with the addition of glycerine in an internal combustion engine. The test engine is a Fiat 1100 MPI spark ignition engine. Five different fuel mixtures were burned in the engine, whose composition and properties are shown in Table 3.

Table 3. Properties of fuels used in research [7]

\begin{tabular}{|l|c|c|c|c|c|}
\hline \multicolumn{1}{|c|}{ Fuel } & E95 & Metanol & $\begin{array}{c}\text { Metanol } \\
+10 \%\end{array}$ & $\begin{array}{c}\text { Metanol } \\
+20 \%\end{array}$ & $\begin{array}{c}\text { Metanol } \\
+30 \%\end{array}$ \\
\hline Density $\left[\mathrm{kg} / \mathrm{dm}^{3}\right]$ & 0.74 & 0.796 & 0.842 & 0.889 & 0.935 \\
\hline $\begin{array}{l}\text { Calorific value } \\
{[\mathrm{MJ} / \mathrm{kg}]}\end{array}$ & 42.5 & 19.5 & 15.9 & 16.2 & 16.6 \\
\hline Octane number & 95 & 115 & - & - & - \\
\hline
\end{tabular}

The diagrams in Figure 1 show the efficiency of the fueled engine from Table 3 during three trials at different engine speeds. The graphs were prepared as a function of the engine torque. The first trial at a speed of $2000 \mathrm{rpm}$, the second at $2500 \mathrm{rpm}$, the third at $3000 \mathrm{rpm}$. The highest efficiency index was characterized by a methanol mixture with a $10 \%$ addition of glycerol.

The tests also included an assessment of the content of toxic exhaust components. The analysis was based on commercial supply of unleaded petrol 95, methanol and methanol with $10 \%$ addition of glycerol. Figure 2 presents graphs of the content of individual toxic components of exhaust gases as a function of engine torque.

Conclusions from the conducted studies concerning the addition of glycerol indicate that when using alcohol to power a spark-ignition engine, it resulted in increased efficiency and reduced emission of toxic exhaust components. The addition of small amounts of glycerol may lead, in the 
area of medium and high engine loads, to increased $\mathrm{NO}_{\mathrm{x}}$ emissions compared to pure methanol feed. The addition of glycerine as a fuel intended for spark-ignition engines should not exceed $10 \%$ of mixtures with methanol and ethanol.
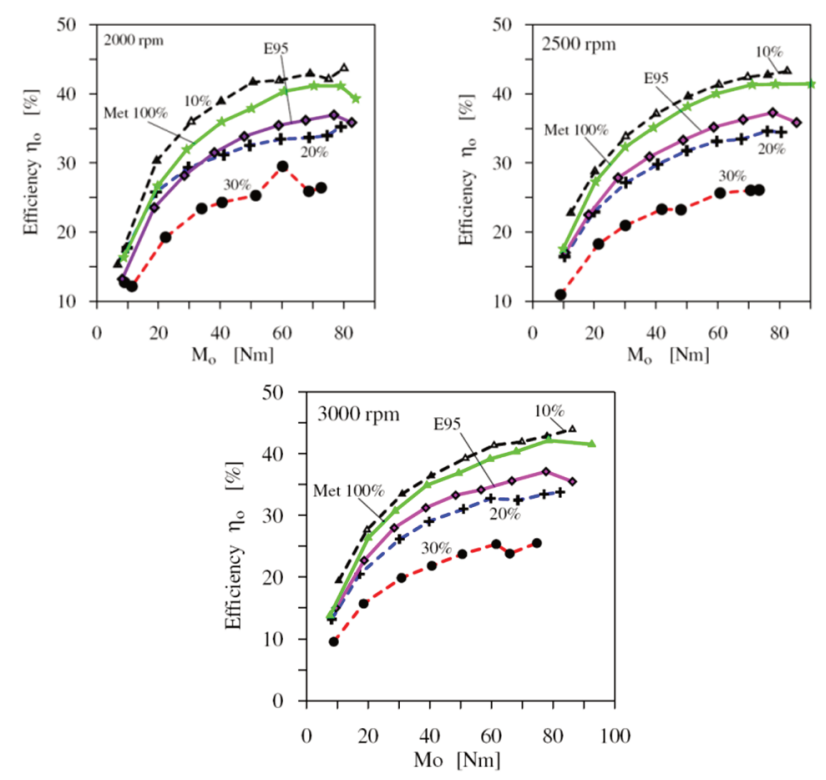

Fig. 1. Efficiency of the engine as a function of torque when fed with different fuel mixtures [7]
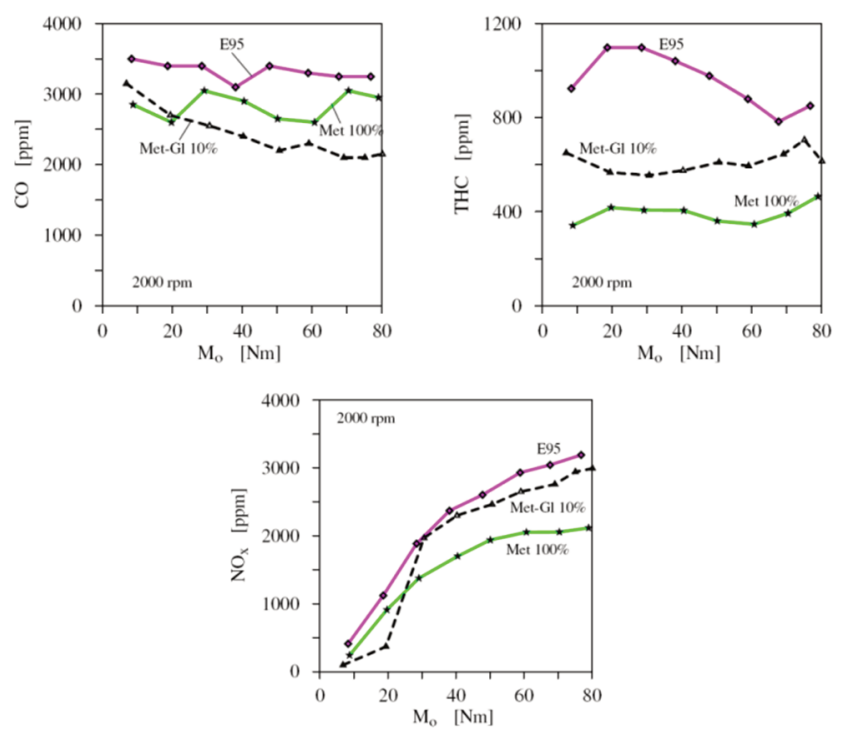

Fig. 2. Content of toxic components of flue gas resulting from the combustion of various fuel mixtures [7]

\subsection{Supplying the SI engine with synthesis gas from glycerine}

Synthesis gas has long been used as fuel for the combustion engines. Syngas is a mixture of carbon monoxide, carbon dioxide, methane and hydrogen. The content of individual components is variable and results from the selection of process parameters and the type of raw material used for production. The synthesis gas can be obtained from gaseous and liquid hydrocarbons, alcohols and carbohydrates. One of the compounds that can be used to obtain it is glycerol.
The research [13] of Dereck Kyle Pickett from 2013 at Univesity of Kansas consisted in powering a spark-ignition gas engine produced from glycerol and propane for comparison purposes. We successfully managed to power the engine using gas synthesized from glycerine. The author of the project defines three states of the reactor, in which it obtains different proportions of the syngas components. It defines them: No Load, One Load and Two Loads. Table 4 shows the individual proportions of the components of the gas obtained.

Table 4. Definition of the proportion of syngas components [13]

\begin{tabular}{|l|l|c|}
\hline \multirow{4}{*}{ No Load } & Component & Volume $[\mu \mathrm{l}]$ \\
\cline { 2 - 3 } & Hydrogen & 18.017 \\
\cline { 2 - 3 } & Methane & 0.477 \\
\cline { 2 - 3 } & $\mathrm{CO}$ & 18.431 \\
\cline { 2 - 3 } & $\mathrm{CO}_{2}$ & 8.680 \\
\cline { 2 - 3 } & Ethylene & 4.105 \\
\cline { 2 - 3 } & Ethane & 2.284 \\
\hline \multirow{4}{*}{ One Load } & Hydrogen & 20.629 \\
\cline { 2 - 3 } & Methane & 0.599 \\
\cline { 2 - 3 } & CO & 14.935 \\
\cline { 2 - 3 } & CO & 5.984 \\
\cline { 2 - 3 } & Ethylene & 3.789 \\
\cline { 2 - 3 } & Ethane & 2.103 \\
\hline \multirow{7}{*}{ Two Loads } & Hydrogen & 26.548 \\
\cline { 2 - 3 } & Methane & 4.322 \\
\cline { 2 - 3 } & CO & 13.608 \\
\cline { 2 - 3 } & CO & 5.388 \\
\cline { 2 - 3 } & Ethylene & 3.628 \\
\cline { 2 - 3 } & Ethane & 1.960 \\
\hline
\end{tabular}

Figures 3-5 illustrate the course of the cylinder pressure relative to the angle of rotation of the crankshaft for the individual three compositions of the synthesis gas obtained and for the propane feed. The engine on which the tests were carried out is a General Motors V8 engine with a cubic increment of 350 cubic inches.

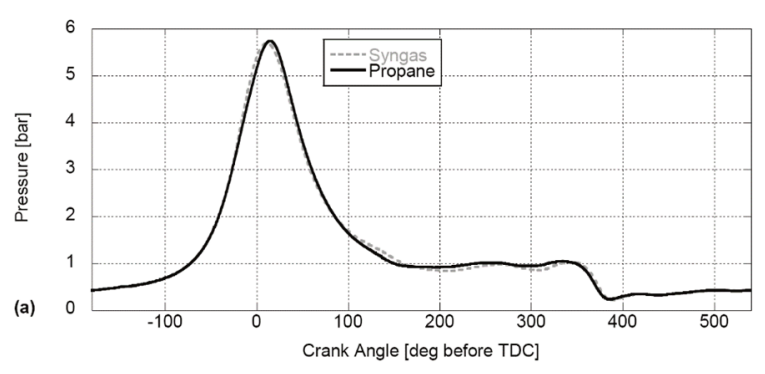

Fig. 3. Pressure course in the combustion chamber as a function of the angle of rotation of the crankshaft for "No Load" [13]

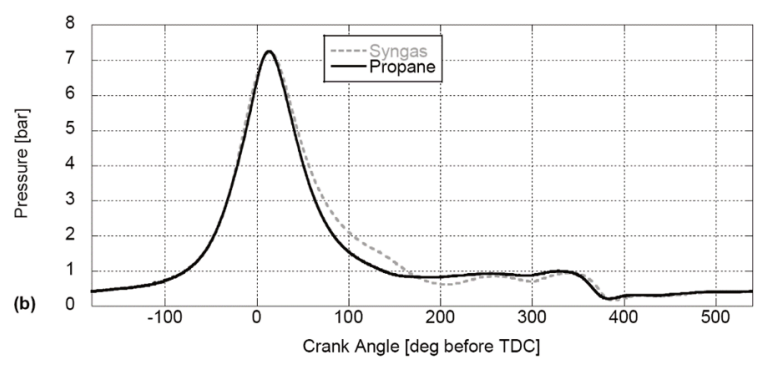

Fig. 4. The pressure course in the combustion chamber as a function of the crankshaft rotation angle for "One Load" [13] 


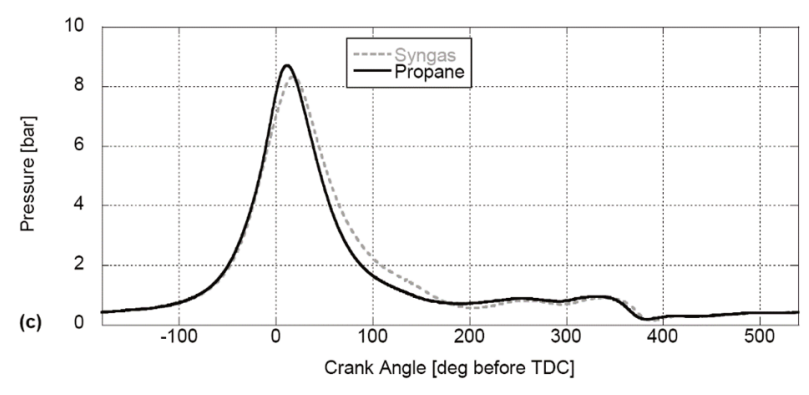

Fig. 5. The course of pressure in the combustion chamber as a function of the angle of rotation of the crankshaft for "Two Loads" [13]

The author draws attention to the mistake made during the test consisting in the lack of regulation of valves supplying the engine with gas. Also the ignition advance angle was the same in the case of propane and synthesis gas supply. This influenced the operation of the engine on the synthesis gas on a richer mixture, which resulted in incomplete and incomplete combustion, which was reflected in emissions, $\mathrm{CO}, \mathrm{CO}_{2}$ and $\mathrm{HC}$ residues. During the syngas feed the EGR system was additionally switched on. The difference in the course of curves visible at higher loads in Fig. 4 and 5 is due to the fact that due to the lower calorific value of syngas compared to propane, a larger gas mass was introduced into the charge and exhaust gas recirculation was used, which resulted in a longer combustion time. The analysis of the research presented in the above works concerning the combustion of glycerol and synthesis gas originating from glycerine provided important conclusions. Combustion of unprocessed glycerine is very difficult. In a spark-ignition engine, the main problem is the supply of glycerol by injectors due to its high viscosity, which affects its spraying and, consequently, the stable and efficient operation of the engine. Detailed studies on the burning of glycerol in a laminar manner, and the study of its physical properties are contained in the article [19].

Attempts to feed spark ignition engines using glycerine as an additive to other fuels, in particular alcohols such as methanol or ethanol, have shown a significantly improved fuel combustion efficiency. The question is whether additions of glycerine to traditional commercial gasoline can increase the efficiency of the engine.

Powering the SI engine using synthesis gas made of glycerine is an interesting alternative. The full so-called analysis of environmental impacts of toxic substances accompanying the production of such a fuel. An additional issue concerning the future of supplying engines with syngas is the method of fuel storage. Should it be done as shown in the history from the beginning of the 20th century where the gas generator was in the car or whether to produce syngas in stationary generators.

\section{Methods for gasification of glycerine}

As it has already been pointed out, the production and use of glycerine is on the one hand related to the scale of biodiesel production, and on the other hand to the development of new processes and technologies of its utilization. Among all possible and technically and physically available methods, the conversion of glycerol to valuable gases such as hydrogen and synthesis gas used as a valuable en- ergy carrier - is one of the most attractive ways of aggregating glycerol values [4].

The reforming processes used for the production of hydrogen and synthesis gas from glycerine cover a number of processes and technologies, and in the literature there are many articles on this subject. These articles mainly characterize the "catalytic behavior" of the applied systems. The following methods for reforming glycerol may be mentioned:

- steam reforming (SR) [20-26],

- partial oxidation (or oxidative reform) (PO) [27-29],

- autothermal reforming (ATR) [27, 29] and supercritical water gasification (SCWG) [30-34],

- dry reforming (or $\mathrm{CO}_{2}$ reforming) (DR) [36, 37],

- autothermal dry (and also a combination of dry, oxidation and steam reforming) [37] and pyrolysis [38].

\section{Selection of the method due to the possibility of using waste heat from the engine}

The use of glycerine for energy purposes brings with it the so-called pro-ecological effect in the form of lower emission of carbon dioxide in relation to the unit weight of fuel. The measurable value of this effect depends on the degree of purity of the glycerine used. For obvious reasons in the utilization processes, the most desirable option is to use the least processed waste - we are interested in the socalled $80 \%$ of the technical glycerine remained after the production of biodiesel, table 7 . Therefore, in the case of the utilization of this glycerine, one should look for a method that forms part of this postulate. The most rational seems to be here, the use of the so-called waste heat from thermodynamic processes carried out in a piston combustion engine. We mean the energy stream discharged into the atmosphere in the exhaust. In connection with the above, we proposed the use of a modified method of reforming steam glycerine on a catalytic bed. The project included the construction of a dedicated reactor, in which superheated steam of a glycerol water solution under a slight overpressure of $120 \mathrm{kPa}$, at a temperature of approximately $330^{\circ} \mathrm{C}$, reacted on a ceramic catalytic bed. The process diagram is shown in Fig. 6, and the view of the reactor during tests is shown in Fig. 7.

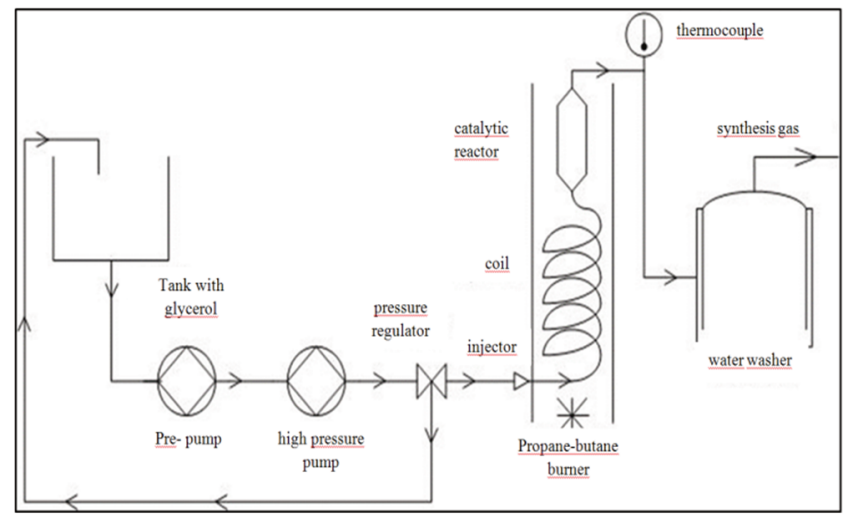

Fig. 6. Diagram of the installation for the production of syngas

During the attempts to obtain syngas, both pure glycerine with a concentration of $99.5 \%$ was used. and technical 
at $80 \%$ concentration. For production, the above-mentioned a reactor in which the glycerine and its vapors were heated by flowing hot flue gases. Glycerine was injected into a unilaterally closed coil, and then as a result of pressure increase, the vapor passed to a catalytic reactor in which the synthesis gas was produced.

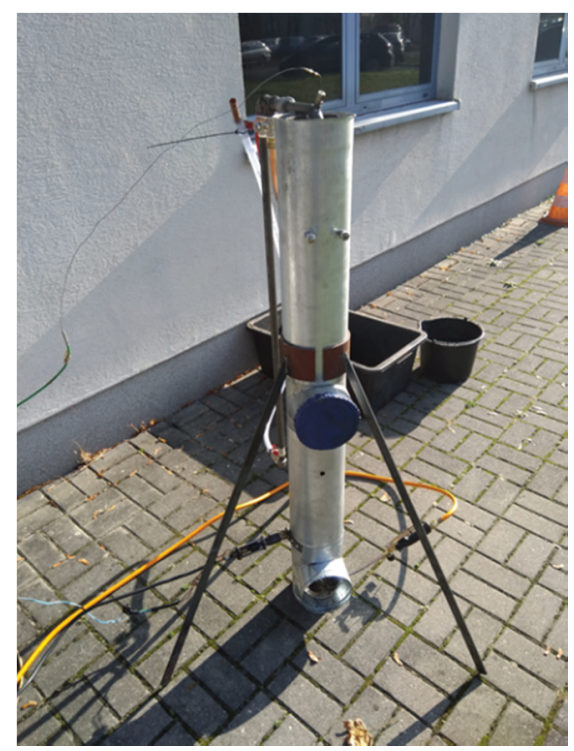

Fig. 7. A reactor for the production of synthesis gas

\section{Results of production of syngas}

The tables below contain the numerical values of volume constituents of gaseous components, so-called synthesis gas, produced using different varieties of glycerol, for different values of thermodynamic parameters of the reforming process, including reforming of steam glycerine on a catalytic bed.

Table 5 presents the chemical composition of synthesis gas obtained in the $99.5 \%$ glycerine reforming process. The table also contains information about the gas temperature at the outlet of the catalytic converter. Three gas samples obtained at different temperatures of the catalytic converter were analyzed.

Table 5. Composition of synthesis gas obtained from glycerol at a concentration of $99.5 \%$

\begin{tabular}{|c|c|c|c|c|c|c|}
\hline Sample number & $\begin{array}{c}\text { Temperature } \\
{\left[{ }^{\circ} \mathrm{C}\right]}\end{array}$ & $\begin{array}{c}\mathrm{H}_{2} \\
{[\%]}\end{array}$ & $\begin{array}{c}\mathrm{O}_{2} \\
{[\%]}\end{array}$ & $\begin{array}{c}\mathrm{N}_{2} \\
{[\%]}\end{array}$ & $\begin{array}{c}\mathrm{CO}_{2} \\
{[\%]}\end{array}$ & $\begin{array}{c}\mathrm{CH}_{4} \\
{[\%]}\end{array}$ \\
\hline 1 & 250 & 19.94 & 6.37 & 24.42 & 2.74 & 23.62 \\
\hline 2 & 270 & 23.96 & 2.16 & 8.59 & 3.80 & 29.32 \\
\hline 3 & 300 & 24.31 & 0.69 & 2.53 & 5.50 & 30.40 \\
\hline
\end{tabular}

Table 6 presents the chemical composition of the syngas, which was also produced in the above-mentioned in a reactor, if $20 \%$ water is added to pure glycerine. The reaction taking place inside the catalytic reactor was carried out at a higher temperature than before.

Table 6. Composition of synthesis gas obtained from glycerol at a concentration of $99.5 \%$ with the addition of $20 \%$ water

\begin{tabular}{|c|c|c|c|c|c|c|}
\hline Sample number & $\begin{array}{c}\text { Temperature } \\
{\left[{ }^{\circ} \mathrm{C}\right]}\end{array}$ & $\begin{array}{c}\mathrm{H}_{2} \\
{[\%]}\end{array}$ & $\begin{array}{c}\mathrm{O}_{2} \\
{[\%]}\end{array}$ & $\begin{array}{c}\mathrm{N}_{2} \\
{[\%]}\end{array}$ & $\begin{array}{c}\mathrm{CO}_{2} \\
{[\%]}\end{array}$ & $\begin{array}{c}\mathrm{CH}_{4} \\
{[\%]}\end{array}$ \\
\hline 1 & 316 & 28.66 & 1.41 & 5.53 & 9.63 & 24.60 \\
\hline 2 & 350 & 28.03 & 1.97 & 7.30 & 13.87 & 21.53 \\
\hline 3 & 389 & 30.46 & 2.03 & 7.80 & 17.50 & 19.20 \\
\hline
\end{tabular}

Table 8 contains the results of the analysis of the chemical composition of syngas, which was produced as a result of the use of the technical glycerine composition shown in Table 7.

Table 7. The composition of technical glycerine

\begin{tabular}{|l|c|}
\hline Component & content \% \\
\hline Glycerine & 72.5 \\
\hline Water & 15 \\
\hline Ash & 7 \\
\hline $\begin{array}{l}\text { MONG (organic compounds except glyc- } \\
\text { erol) }\end{array}$ & 5 \\
\hline Methanol & 0.5 \\
\hline
\end{tabular}

Table 8. Composition of synthesis gas obtained from technical glycerine

\begin{tabular}{|c|c|c|c|c|c|}
\hline $\begin{array}{c}\text { Temperature } \\
{\left[{ }^{\circ} \mathrm{C}\right]}\end{array}$ & $\begin{array}{c}\mathrm{H}_{2} \\
{[\%]}\end{array}$ & $\begin{array}{c}\mathrm{O}_{2} \\
{[\%]}\end{array}$ & $\begin{array}{c}\mathrm{N}_{2} \\
{[\%]}\end{array}$ & $\begin{array}{c}\mathrm{CO}_{2} \\
{[\%]}\end{array}$ & $\begin{array}{c}\mathrm{CH}_{4} \\
{[\%]}\end{array}$ \\
\hline 350 & 36.53 & 0.3 & 1.14 & 6.89 & 34.10 \\
\hline
\end{tabular}

Synthesis gas obtained from technical glycerine at a temperature of $350^{\circ} \mathrm{C}$ is characterized by the highest content of combustible components in its volume. The experiment was to show whether it is possible to obtain valuable synthesis gas in terms of using it to power SI engines with the possibility of using the energy of exhaust gases coming from the engine to conduct the reaction. The content of combustible components of synthesis gas was reached at the level of $70 \%$ of the gas volume. The synthesis gas obtained in accordance with the conditions of the above test was used to power the SI engine.

\section{Supplying the SI engine with synthesis gas from glycerine}

The tests were carried out on a two-cylinder, four-stroke SI engine with a displacement of $0.65 \mathrm{dm}^{3}$, with a constant crankshaft speed of $25001 / \mathrm{min}$. During the tests, the engine was powered by two fuels through a mixer installation. Comparative measurements were made on LPG fuel. Due to the initial character of motor tests, the engine operation indicators were registered only in two points of the field of work on the regulatory characteristics of the mixture composition. During engine operation, measurements of such quantities as:

- torque

- exhaust gas temperature of individual cylinders

- lambda value

- concentrations of exhaust components: $\mathrm{CO}, \mathrm{CO}_{2}, \mathrm{HC}, \mathrm{NO}_{\mathrm{x}}$

Table 9 presents comparative data during operation of the engine powered by LPG.

Table 9. Measurement data of the operation of the engine powered by LPG

\begin{tabular}{|c|c|c|c|c|c|c|c|c|}
\hline $\begin{array}{c}\mathrm{M} \\
{[\mathrm{Nm}]}\end{array}$ & $\begin{array}{c}\mathrm{N} \\
{[\mathrm{kW}]}\end{array}$ & $\begin{array}{c}\mathrm{T}_{\mathrm{S} 1} \\
{\left[{ }^{\circ} \mathrm{C}\right]}\end{array}$ & $\begin{array}{c}\mathrm{T}_{\mathrm{S} 2} \\
{\left[{ }^{\circ} \mathrm{C}\right]}\end{array}$ & $\lambda$ & $\begin{array}{c}\mathrm{CO} \\
{[\%]}\end{array}$ & $\begin{array}{c}\mathrm{CO}_{2} \\
{[\%]}\end{array}$ & $\begin{array}{c}\mathrm{HC} \\
{[\mathrm{ppm}]}\end{array}$ & $\begin{array}{c}\mathrm{NO}_{\mathrm{X}} \\
{[\mathrm{ppm}]}\end{array}$ \\
\hline 18.05 & 4.87 & 699 & 711 & 1.55 & 0.09 & 8.6 & 67 & 499 \\
\hline 23.64 & 6.38 & 652 & 655 & 1.01 & 4.74 & 8.4 & 252 & 338 \\
\hline
\end{tabular}

Table 10 shows the data during the operation of the engine powered by synthesis gas.

With unchanged throttle position adjustment settings and ignition timing values, a drop in the torque value was noted when feeding the synthesis gas during the enrichment 
of the mixture. This is related to the lower value of the synthesis gas energy parameters. At the same time, a drop in $\mathrm{CO}_{2}$ concentration was observed with this gas. Due to the simplified methodology of motor measurements, further investigation will be devoted to this issue. Despite a very fragmentary research program, in the case of engine operation on the above synthesis gas, a typical for this fuel was found a very stable course of the formation of a combustible mixture, using a simple power supply system.

Table 10. Measurement data of the engine operation when fed with synthesis gas

\begin{tabular}{|c|c|c|c|c|c|c|c|c|}
\hline $\begin{array}{c}\mathrm{M} \\
{[\mathrm{Nm}]}\end{array}$ & $\begin{array}{c}\mathrm{N} \\
{[\mathrm{kW}]}\end{array}$ & $\begin{array}{c}\mathrm{T}_{\mathrm{S} 1} \\
{\left[{ }^{\circ} \mathrm{C}\right]}\end{array}$ & $\begin{array}{c}\mathrm{T}_{\mathrm{S} 2} \\
{\left[{ }^{\circ} \mathrm{C}\right]}\end{array}$ & $\lambda$ & $\begin{array}{c}\mathrm{CO} \\
{[\%]}\end{array}$ & $\begin{array}{c}\mathrm{CO}_{2} \\
{[\%]}\end{array}$ & $\begin{array}{c}\mathrm{HC} \\
{[\mathrm{ppm}]}\end{array}$ & $\begin{array}{c}\mathrm{NO}_{\mathrm{x}} \\
{[\mathrm{ppm}]}\end{array}$ \\
\hline 18.15 & 4.89 & 630 & 629 & 1.4 & 0.17 & 4.7 & 45 & 814 \\
\hline 19.12 & 5.16 & 630 & 623 & 1.02 & 0.17 & 6.2 & 45 & 912 \\
\hline
\end{tabular}

\section{Analysis of results}

Attempts were made to produce syngas in variants allowing gas analysis to be used to power the SI motor. In the first case glycerine with a concentration of $99.5 \%$ was used. A gas was obtained which is a mixture of combustible components in a gas volume of about $45-50 \%$. The process temperature did not exceed $300^{\circ} \mathrm{C}$. It is noticeable that the percentage of combustible components in the gas volume increases with increasing process temperature.

The addition of $20 \%$ water to pure glycerine maintains the proportion of combustible parts in the gas composition of about $50 \%$. With the increase of the temperature of the process, a reduction in the proportion of $\mathrm{CH}_{4}$ in the volume is noticeable. The volume of $\mathrm{CO}_{2}$ is almost doubled, and the increase in the share of $\mathrm{H}_{2}$ is insignificant. In the first case, as the temperature increased, it was possible to observe an increase in the proportion of combustible components in the volume. In the second case, the share stays on a more or less stable level, but it can be seen that the addition of water causes a change in the proportion of $\mathrm{CH}_{4}$ and $\mathrm{CO}_{2}$ shares with small changes in the other components. The use of technical glycerine in the third case resulted in the highest share of combustible components in the volume. Water and other technical glycerine components had a beneficial effect on the production process of synthesis gas. The graph shown in Figure 8 illustrates the contribution to the volume of individual components of the synthesis gas, which was used to power the engine in the further part of the study.

For the production of syngas, an average of $100 \mathrm{~g}$ glycerine was consumed during every 15 minutes of the reactor operation. The obtained amount of synthesis gas from $100 \mathrm{~g}$ glycerine is on average 40.61 when producing a total of 10001 of syngas.

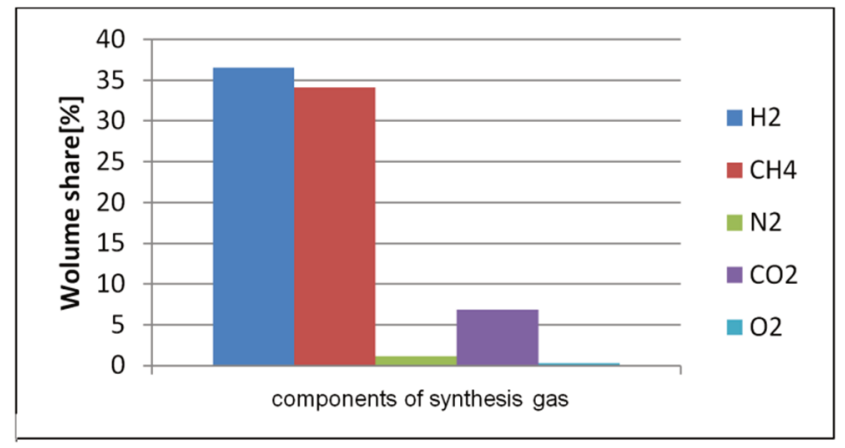

Fig. 8. Volume fraction of syngas components

Each average of approximately $4.17 \mathrm{kWh}$ of energy was used to process each $100 \mathrm{~g}$ glycerol. A total of $1 \mathrm{~m}^{3}$ of syngas was produced for engine tests. About $2.5 \mathrm{~kg}$ of glycerine was used to produce this volume of synthesis gas.

Comparison of the operation of the engine powered by LPG and synthesis gas shows the fundamental difference in fuel consumption. The consumption of synthesis gas is several times greater than the consumption of LPG. This is due to the significantly lower heating value of synthesis gas and the heating value of the syngas and air mixture. There is also a difference in the temperature of the exhaust gas. The temperature of exhaust gases in the case of synthesis gas combustion is lower by several dozen degrees. The reason for the lower exhaust gas temperature for synthesis gas is the different heat recovery process. The content of toxic exhaust components is as follows. An almost two-fold increase in the $\mathrm{CO}$ share in the exhaust composition is visible, but it does not exceed $0.2 \%$. For comparison, vehicles homologated until June 1995 must meet the CO emission standard in Poland up to $3.5 \%$. $\mathrm{CO}_{2}$ emissions are at a comparable level. There are discrepancies, but with a small number of comparative measuring points, they are negligible. There is a clear drop in hydrocarbon emission. There has been an almost two-fold reduction in the emission of this toxic exhaust component, which is due to the fact that synthesis gas consists of much simpler molecules than LPG. Comparison of $\mathrm{NO}_{\mathrm{x}}$ emissions is impossible due to the large discrepancy between measurement data when the engine is running on LPG. A small amount of measurement data does not allow to clearly determine the difference or similarity in the amount of $\mathrm{NO}_{\mathrm{x}}$ particles emitted when burning both fuels.

\section{Bibliography}

[1] BOROWIECKI, T., RYCZKOWSKI, J. Procesy i Katalizatory pozyskiwania gazu syntezowego. Uniwersytet Chemii w Lublinie, Instytut Nawozów Sztucznych w Puławach.

[2] PAŃCZYK, M., BOROWIECKI, T. Otrzymywanie i zastosowanie gazu syntezowego. Zakład technologii chemicznej, Wydziat Chemii Uniwersytetu w Lublinie.

[3] CHMIELNIAK, T., STELMACH, S. Współczesne technologie zgazowania węgla. Problemy Ekologii. 2009, 2.

[4] PIETRZKIEWICZ, L. I co z węglem? Chemia przemystowa. 2011, 1.

[5] KIJEŃSKI, J., KRAWCZYK, Z. Perspektywy rynku gliceryny. Przemyst chemiczny. 2007, 4.

[6] RYCHLIK, A., KIBALCZYC, Ł. Application of glycerine for powering piston diesel engines of large power. Combustion Engines. 2015, 162.

[7] STELMASIAK, Z., PIETRAS, D. Utilization of waste glycerine to fuelling of spark ignition engines. Materials Science and Engineering. 2016, 148. 
[8] CHMIELNIAK, T., POPOWICZ, J. Fluidalne zgazowanie węgla przy użyciu $\mathrm{CO}_{2}$ dla produkcji gazu syntezowego. Chemik. 2013, 67.

[9] DĄBROWSKI, W., BEDNARSKI, W. Ekologiczne aspekty produkcji oraz stosowania biodiesla. Nauki inżynierskie $i$ technologie. 2013, 10.

[10] ZASTĘPOWSKI, M., KASZKOWIAK, J., BOROWSKI, S. et al. pływ zastosowania paliwa $\mathrm{z}$ dodatkiem alkoholu na efektywność pracy silników spalinowych. Logistyka. 2012, 6.

[11] IGLIŃSKI, B., KUJAWSKI, W., BUCZKOWSKI, R., IGLIŃSKA, A. Ekologiczne efekty stosowania biopaliw. Wydział Ochrony Środowiska, Uniwersytet Toruński.

[12] KUBALA, A. Efekty termiczne przy odwadnianiu etanolu w cyklicznym procesie adsorpcyjno-desorbcyjnym zmiennociśnieniowym. PK Wydziat Inżynierii $i$ Technologii Chemicznej.

[13] PICKETT, D.K. Design and operation of the synthesis gas generator system for reformed propane and glycerine combustion. University of Kansas. 2013.

[14] PALARSKI, J. Pozyskiwanie metodami niekonwencjonalnymi energii $\mathrm{z}$ pozabilansowych pokładów węgla $\mathrm{z}$ uwzględnieniem ograniczenia emisji $\mathrm{CO}_{2}$. Górnictwo i Geologia. 2010, 5(1).

[15] STRUGAŁA, A., CZERSKI, G. Badania nad technologiami zgazowania węgla w Polsce. Przemyst Chemiczny. 2012.

[16] BEDNARCZYK, J. Rozwój technologii podziemnego zgazowania węgla i perspektywy jej przemysłowego wdrożenia. Górnictwo i Geoinżynieria. 2007.

[17] SARBAK, Z. Gaz syntezowy i jego przemiany. LAB 2018, 6.

[18] SILVEY, L.G. Hydrogen and syngas production from derived crude glycerol. Univesity of Kansas. 2011.

[19] JACH, A., CIEŚLAK, I., TEODORCZYK, A. Investigation of glicerol doping on ignition delay times and laminar burning velocites of gasoline and diesel fuel. Combustion Engines. 2017, 169.

[20] ZHANG, B., TANG, X., LI, Y. et al. Hydrogen production from steam reforming of ethanol and glycerol over ceria supported metal catalysts. International Journal of Hydrogen Energy. 2007, 32, 2367-2373.

[21] BUFFONI, I.N., POMPEO, F., SANTORI, G.F., NICHIO, N.N. Nickel catalysts applied in steam reforming of glycerol for hydrogen production. Catalysis communications. 2009, 10, 1656-1660.

[22] ADHIKARI, S., FERNANDO, S.D., HARYANTO, A. Hydrogen production from glicerin by steam reforming over nickel catalysts. Renewable Energy. 2008, 33, 1097-1100.

[23] THYSSEN, V.V., MAIA, T.A., ASSAF, E.M. Ni supported on $\mathrm{La}_{2} \mathrm{O}_{3}-\mathrm{SiO}_{2}$ used to catalyze glycerol steam reforming. Fuel. 2013, 105, 358-363.

[24] IRIONDO, A., BARRIO, V.L., CAMBRA, J.F. et al. Glycerol steam reforming over Ni catalysts supported on ceria and ceria promoted alumina. International Journal of Hydrogen Energy. 2010, 35, 11622-11633.

[25] POMPEO, F., SANTORI, G.F., NICHIO, N.N. Hydrogen production by glycerol steam reforming with $\mathrm{Pt} / \mathrm{SiO}_{2}$ and $\mathrm{Ni} / \mathrm{SiO}_{2}$ catalysts. Catalysis Today. 2011, 172, 183-188.

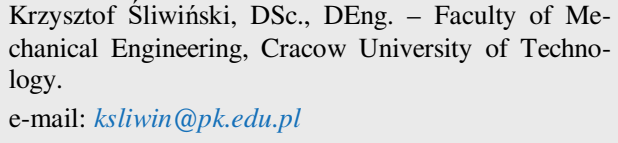

[26] POMPEO, F., SANTORI, G.F., NICHIO, N.N. Hydrogen and/or syngas from steam reforming of glycerol. Study of platinum catalysts. International Journal of Hydrogen Energy. 2010, 35, 8912-8920.

[27] WANG, H., WANG, X., LI, M. et al. Thermodynamic analysis of hydrogen production from glycerol autothermal reforming. International Journal of Hydrogen Energy. 2009, 34, 5683-5690.

[28] WANG, W. Thermodynamic analysis of glycerol partial oxidation for hydrogen production. Fuel Processing Technology. 2010, 91, 1401-1408.

[29] YANG, G., YU, H., PENG, F. et al. . Thermodynamic analysis of hydrogen generation via oxidative steam reforming of glycerol. Renewable Energy. 2011, 36, 2120-2127.

[30] BYRD, A.J., PANT, K.K., GUPTA, R.B. Hydrogen production from glycerol by reforming in supercritical water over $\mathrm{Ru} / \mathrm{Al}_{2} \mathrm{O}_{3}$ catalyst. Fuel. 2008, 87, 2956-2960.

[31] CHAKINALA, A.G., BRILMAN, D.W.F, VAN SWAAIJ, W.P.M., KERSTEN, S.R.A. Catalytic and non catalytic supercritical water gasification of microalgae and glycerol. Industral \& Engineering Chemistry Research. 2009, 49, 11131122.

[32] GUO, S., GUO, L., CAO, C. et al. Hydrogen production from glycerol by supercritical water gasification in a continuos flow tubular reactor. International Journal of Hydrogen Energy. 2012, 37, 5559-5568.

[33] VAN BENNEKON, J.G., VENDERBOSCH, R.H., ASSINK, D., HEERES, H.J. Reforming of methanol and glycerol in supercritical water. The Journal of Supercritical Fluids. 2011, 58, 99-113.

[34] VOLL, F.A.P., ROSSI, C.C.R.S., SILVA, C. et al. Thermodynamic analysis of supercritical water gasification of methanol, ethanol, glycerol, glucose and cellulose. International Journal of Hydrogen Energy. 2009, 34, 9737-9744.

[35] WANG, X., LI, M., WANG, M. et al. Thermodynamic analysis of glycerol dry reforming for hydrogen and synthesis gas production. Fuel. 2009, 88, 2148-2153.

[36] FERNÁNDEZ, Y., ARENNILAS, A., BERMÚDEZ, J.M., MENÉNDEZ, J.A. Comparative study of conventional and microwave assisted pyrolysis, steam and dry reforming of glycerol for syngas production, using a carbonaceous catalyst. Journal of Analytical and Applied Pyrolysis. 2010, 88, 155-159.

[37] KALE, G.R., KULKARNI, B.D. Thermodynamic analysis of dry autothermal reforming of glycerol. Fuel Processing Technology. 2010, 91, 520-530.

[38] VALLIYAPPAN, T., BAKHSHI, N.N., DALAI, A.K. Pyrolysis of glycerol for the production of hydrogen or syngas. Bioresource Technology. 2008, 99, 4476-4483.

[39] Grab-Rogaliński K., Szwaja S. The possibililty of use a waste product of biofules production - glycerol as a fuel to the compression ignition engine. Journal of KONES. 2016, 23(3).

Wojciech Marek, DSc., DEng. - Professor in the Faculty of Mechanical Engineering, Cracow University of Technology. e-mail:wmarek@pk.edu.pl 